\title{
Inherit the Red Gene and Construct the Second Classroom Path of Red Culture-Take the Promotion of the Red Spirit of Jinggang Mountain as an Example
}

\author{
Daiwei Meng, Yingyi Lei \\ Xi'an Aviation University Youth League Committee, Xi'an, Shaanxi, China
}

\begin{abstract}
Carrying forward the Jinggangshan spirit is an important manifestation of inheriting the red gene and feeling the red culture, and it is also an important support for constructing the ideological education system of colleges and universities. This article starts with expounding the rich connotation of Jinggangshan spirit, analyzes the significance of constructing the second classroom of red culture in the ideological education system of colleges and universities, and explores the way to construct the second classroom of red culture in colleges and universities taking Jinggangshan spirit as an example.
\end{abstract}

Keywords: Jinggangshan Spirit; Second Classroom; Path Exploration

The construction of the second-class ideological education system with the inheritance of the red gene as the carrier is an important measure for colleges and universities to promote the fundamental task of cultivating high-quality talents under the pattern of "big ideological politics". In this paper, through the profound exposition of the rich connotation of Jinggangshan spirit, it summarizes and analyzes the significance of constructing the second classroom of red culture in the ideological education system of colleges and universities, and combines the current ideological education work of colleges and universities and the actual construction of the second classroom education platform. Explore the way to build a second classroom ideological education system for the red culture in colleges and universities represented by the Jinggangshan spirit.

\section{Deeply grasp the rich connotation of Jinggangshan spirit}

General Secretary Xi pointed out: "The most precious wealth left to us during the Jinggangshan period is the Jinggangshan spirit that spans time and space." The so-called Jinggangshan spirit that spans time and space is to persevere in pursuing ideals, seeking truth from facts to break new paths, struggling hard to overcome difficulties, and relying on the people to ask. The great revolutionary spirit of victory. It embodies the unity of Marxist beliefs of "knowledge, affection, intention and behavior", points out the direction for the construction of the ideological education system of colleges and universities, and has a strong education function. The following will elaborate on the rich connotations of Jinggangshan's revolutionary spirit from the aspects of firm ideals and beliefs, hard work, seeking truth from facts, brave struggle, relying on the masses, and brave victory.

(1) Firm ideals and beliefs and hard work are the foundation of the Jinggangshan spirit. When the Chinese Revolution was in a difficult situation in development, in the Jinggangshan Revolutionary Base, the Chinese Communists relied on their firm belief and unremitting pursuit to realize their ideals and beliefs without fear of hardship, pioneering and innovating, dedication and selfless dedication. Eventually withstood the baptism of weather and the test of the revolution, and won the victory of the Jinggangshan revolutionary struggle.

(2) Seeking truth from facts and fighting bravely are the core essence of Jinggangshan spirit. For a long time, hard work has been regarded as the traditional virtue of the Chinese nation, embodies the political nature of the Chinese Communists, and is an indispensable and important part of the Jinggangshan spirit. The struggle in the Jinggangshan Revolutionary Base is against a critical historical background. The Chinese Communists have always adhered to the value concept of seeking truth from facts, linking Marxist theory with the actual situation of the Chinese revolutionary struggle, and pioneering the revolutionary road of encircling the city from the countryside, which is the Chinese revolution. The victory laid a solid foundation.

(3) Relying on the masses and having the courage to win is the fundamental force of the Jinggangshan spirit. In the struggle in the Jinggangshan Revolutionary Base, doing mass work was one of the "three major tasks" formulated during the Jinggangshan Revolution. Through the development of mass work, the consciousness of the masses has been inspired and the demands of the 
masses have been listened to. Fully mobilize, organize, and unite the broad masses of forces to invest in the revolution. Under the extremely difficult conditions at the time, the fundamental reason that a single spark could quickly form a prairie fire and eventually spread to all parts of China was relying on the masses.

\section{The importance of constructing the second classroom of red culture in colleges and universities}

The first classroom of ideological and political theory teaching and the second classroom of red cultural perception together constitute a complete system of ideological education in colleges and universities, and actively lead young students to inherit the red gene from the aspects of thinking and action. Among them, the second classroom of red culture is a new and beneficial exploration of the ideological education model. Compared with the traditional theoretical teaching mode of ideological and political education courses, the construction of the second classroom of red culture mainly allows students to jump out of the daily required courses and volunteer Participate in some useful activities such as visits to red sacred places, red spiritual perception, red theory discussions, etc.

(1) Constructing a second classroom of red culture is an effective supplement to traditional ideological and political teaching. In terms of knowledge acquisition, traditional ideological and political teaching methods are mostly based on theoretical teaching. Most course teachers explain textbook knowledge step by step, and some teachers even teach based on textbooks. The channels for students to obtain red cultural knowledge are limited to the textbooks have a weak sense of consciousness. Through the second classroom of red culture, various forms can be adopted, such as red type of social practice activities, club activities and campus cultural activities, etc., to further guide students' on-the-spot perception, active discussion, and let red culture be heard.

(2) Constructing the second classroom of red culture is an important way to lead students to understand the history of the red revolution. The second classroom of red culture has the characteristics of diverse forms of education and wide coverage. During the development of the second classroom, students can come into contact with many situations outside the classroom, such as visiting and practicing in various red bases. This situation will make Students consciously perceive some red spirits, and a large part of these spirits comes from the content learned in daily ideological and political theory courses, so that theoretical knowledge can be confirmed and sublimated. Theoretical knowledge cannot completely make students have a more real historical perception and accept the influence of red culture. The second classroom of red culture can solve this problem with its unique advantages.

\section{The path to construct the second classroom of red culture}

To construct the second classroom of red culture is to integrate red culture into the cultural activities, artistic activities, competitions and various social practice activities in the second classroom of college students, so that college students can always learn and practice in the second classroom. Feel the charm of red culture, enhance understanding of red culture, and consciously become a learner, communicator and practitioner of red culture. This article mainly takes the promotion of Jinggangshan spirit as an example to illustrate the effective way to construct and implement the second classroom of red culture.

(1) Give full play to the effectiveness of the second classroom practice education, highlight the red education module of Jinggangshan spirit. The pure theoretical teaching guidance is difficult to enhance the students' learning experience, and even causes students to have a negative psychology in the learning of ideological and political knowledge content, which is not conducive to the good cultivation of students' ideological and political literacy. Therefore, in the process of exploring the effective integration of Jinggangshan spirit into ideological and political education, we can try to develop various types of social practice activities and permeate the Jinggangshan spirit concept in social practice. The social practice module is an important part of "PU Pocket", "Dream Space", and many other second classroom apps, and it is also the key content of the second classroom credit system assessment in various universities.

(2) Give full play to the advantages of the second classroom propaganda position of red culture and vigorously promote the spirit of Jinggangshan. One is to use new media tools such as WeChat and Douyin to combine "online" and "offline" activities to enhance learning flexibility. Guide the student league branch to establish a Jinggangshan spirit seminar group. The second is to actively play the role of secondary classroom propaganda carriers such as the campus network, school newspapers, and publicity boards to vigorously promote the spirit of Jinggangshan. A special page "Jinggang Mountain Red Gene" was opened on the school's Communist Youth League website to build a network of red genes. On the occasion of major anniversaries and holidays, opening up a red cultural forum and red spiritual wealth theme speeches are all effective ways worth trying. The third is to carry out related commemorative activities in conjunction with the anniversary of major historical events. Carry forward the Red Army's unwavering revolutionary belief and hard-working Jinggangshan revolutionary spirit in various forms of art. The fourth is to invite veterans, old cadres, and descendants of the old Red Army to give reports on revolutionary traditions and tell stories about revolutionary traditions.

(3) Give full play to the main role of the second classroom of red culture in the construction of campus culture, and inherit the red gene of Jinggangshan well. The construction of campus culture is an indispensable part of the ideological and political education of young students, and it is also an important carrier for the inheritance of Jinggangshan's red gene. The rich revolutionary spirit and humanistic and historical content reflected in the red gene of Jinggang Mountain are precious spiritual food for contemporary college students. Through these measures, actively create a spiritual atmosphere compatible with campus culture, so that the red gene of Jinggangshan can penetrate into the university campus as sunlight, air and water. In it, college students can learn nourishment, be nurtured and educated at any time.

\section{Conclusion}

Jinggangshan red culture is a precious red cultural resource left by the revolutionary ancestors. Inheriting the excellent 
revolutionary traditions, carrying forward the precious Jinggangshan red culture, and transforming the red cultural resources into resources for the school's ideological education are not only a useful attempt to make full use of the second classroom of the red culture for characteristic education, but also to implement the education policy of Lide Shuren reflect. In the exploration of the path of spreading the Jinggangshan spirit, colleges and universities must continue to innovate, build a network position, social practice, campus culture, student associations and other red culture second classroom platforms, so that the red gene of the Jinggangshan spirit can be continuously and effectively passed on.

\section{References}

$1 \mathrm{Yu}$ Miao. A four-dimensional analysis of the value of Jinggangshan spirit to the ideological and political education of colleges and universities in the new era [J]. Journal of Changchun Institute of Technology (Social Science Edition), 2019(02): 6-10.

2 Shi Ziliang. The effect of inheriting Jinggangshan spirit on ideological and political education in colleges and universities in the new era [J]. The Collection of Party History (Part 2), 2019(05): 57-59.

3 Chen Qingjiao. The value of Jinggangshan spirit integrated into college students' ideological and political education: Taking Jinggangshan University as an example [J]. Jiangxi Education, 2019(09): 4-5.

4 Yang Lan, Huang Shan. Discussion on the methods and approaches of integrating Jinggangshan spirit into ideological and political education in colleges and universities in the era of "Internet +" [J]. Education Teaching Forum, 2019(06): 50-51.

5 Yan Yuxia. How does the Jinggangshan spirit blend into the ideological and political education of colleges and universities [J]. Culture and Education Data, 2018(09): 104-105.

6 Jiang Chao. Carry forward the spirit of Jinggangshan and promote the innovation of ideological and political education in colleges and universities [J]. Journal of Chongqing Urban Management Vocational College, 2018(01): 55-58.

7 Yan Yuxia. Research on the Jinggangshan Spirit and the Construction of Ideological and Political Education in Colleges and Universities [J]. Old District Construction, 2017(22): 42-45. 